\title{
Minimizing cost of production through introducing community based agricultural mechanization for the smallholders in Bangladesh
}

\begin{abstract}
For achieving food security, Bangladesh has to go for vertical expansion of agricultural output over the current situation of its cultivable land. One of the most important means to boost up the vertical expansion of agricultural production is to adopt small scale agricultural mechanization suitable for the smallholders. In addition rural labour force has started to shift from agricultural to industrial sector and service sector, creating an acute agricultural labour shortage during peak planting and harvesting times which resulting in yield reduction and excess cost of production. This study was an attempt to develop a community based agricultural mechanization for the smallholders by introducing Krishi Sheba based service system in rural Bangladesh. By using Transplanter \& Reaper machine it was possible to save at least 40 labour for a acre of land. On the other hand, it will bring a net income of around Tk. 104000 for a six month period by using this community based service system. Overall, the labor shortage crisis of the community farmers and the cost of production have been minimized significantly.
\end{abstract}

Volume 2 Issue $6-2018$

\section{Md Monirul Islam \\ Department of Agricultural Economics, Bangladesh Agricultural University, Bangladesh}

\section{Correspondence: Md Monirul Islam, Assistant Professor Department of Agricultural Economics, Bangladesh Agricultural University, Mymensingh-2202, Bangladesh,} Email moner.bau_96@yahoo.com

Received: November 25, 2017 | Published: November 30, 2018

\section{Introduction}

By 2050, global population is expected to reach 9.6 billion. ${ }^{1}$ As a result, the consumption of staple cereals, including rice, wheat, maize, as well as fish and meat products is expected to increase dramaticallyparticularly in rapidly developing countries. ${ }^{2}$ This situation has been complicated day by day by decreasing arable agricultural land and migration of active labour from agriculture to non-agriculture sector in Bangladesh. The demand of cereals by the year 2030 has been projected to reach 43.82 million tons at an anticipated per capita income growth rate of $2 \%$. This implies that the production of cereals will have to be increased by 2030. Scope for horizontal expansion of cultivable land is limited. To achieve the increased food production target Bangladesh has to go for vertical expansion of agricultural output over the current situation of its cultivable land. One of the most important means to boost up the vertical expansion of agricultural production is to adopt agricultural mechanization suitable for the Bangladeshi smallholders. Currently, 150 rice reapers and 100 combined harvesters are being used in Bangladesh. The mechanization of rice harvesting has only reached $15 \%$ of the rice planting area. The use of mechanical harvesters in rice production can avoid losses of about 3\% per season. Agricultural labours are decreased from $63 \%$ in 2007 to $47 \%$ in 2012. Moreover, rural labour force has started to shift from agricultural to industrial sector and service sector, creating an acute agricultural labour shortage during peak planting and harvesting times which resulting in yield reduction and excess cost of production.

To establish strategies for the successful mechanization of rice harvesting, it is necessary to find out some alternative ways. Therefore, this study was an attempt to develop a community based agricultural mechanization for the smallholders by introducing Krishi Sheba based service system in rural Bangladesh. Therefore, farm mechanization for the smallholders in Bangladesh is inevitable to reduce the cost of production through introducing community based agricultural mechanization. The theme of this research work was to develop a community based service center which will provide services and training to the small farmers. As smallholders are economically poor they cannot able to purchase modern agricultural machineries. At first we made a cooperative society. There was a project manager from the community, he was known as local service provider (LSP). The community applied for loan to BKB @ 9\% interest rate.

\section{Results at a glance}

Table 1, Table $2 \&$ Figure 1, Figure 2

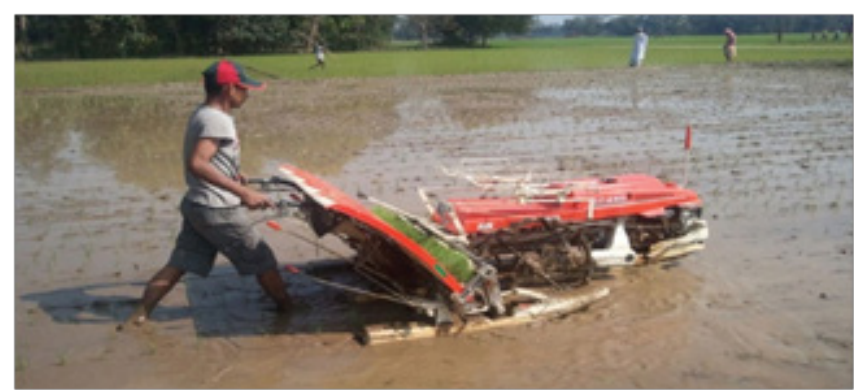

Figure I A farmer is planting rice with Rice Transplanter Machine.

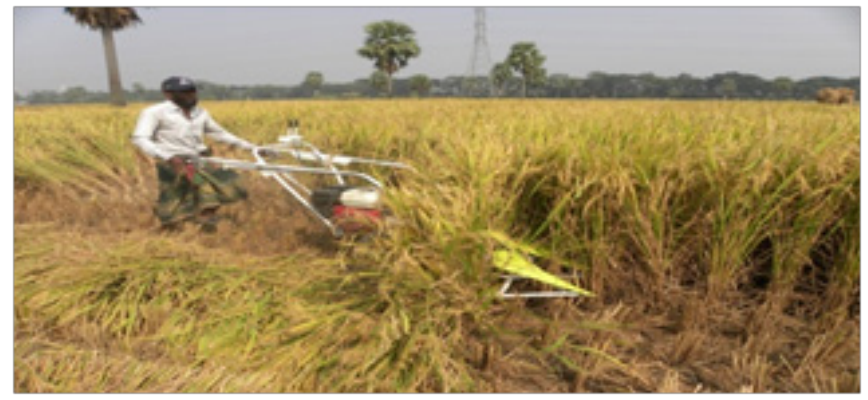

Figure $\mathbf{2} \mathrm{A}$ farmer is cutting rice with reaper machine. 
Table I Comparative analysis of conventional method and modern method (Transplanter \& Reaper) for Producing rice

\begin{tabular}{|c|c|c|c|c|c|c|c|c|c|}
\hline \multirow[t]{2}{*}{ Items } & \multicolumn{3}{|c|}{$\begin{array}{l}\text { Conventional method } \\
\text { (Tk.) }\end{array}$} & \multicolumn{3}{|c|}{$\begin{array}{l}\text { Modern method using rice transplanter } \\
\& \text { reaper machine (Tk.) }\end{array}$} & \multicolumn{3}{|c|}{ Hiring from local merchant farmer (Tk.) } \\
\hline & No. of labor & Wage rate & Cost (Tk.) & No. of labor & Wage rate & Cost (Tk.) & No. of labor & Wage rate & Cost (Tk.) \\
\hline \multirow{2}{*}{$\begin{array}{l}\text { Planting Cost } \\
\text { (Human Labor) }\end{array}$} & \multirow{2}{*}{21} & \multirow{2}{*}{400} & \multirow{2}{*}{8400} & 1 & 450 & 450 & 1 & 450 & 450 \\
\hline & & & & Fuel cost & $1.5 \mathrm{~L} \times 100$ & 150 & Fuel cost & & 150 \\
\hline \multirow{2}{*}{$\begin{array}{l}\text { Harvesting Cost } \\
\text { (Human Labor ) }\end{array}$} & \multirow{2}{*}{21} & \multirow{2}{*}{400} & \multirow{2}{*}{8400} & & 450 & 450 & 1 & 450 & 450 \\
\hline & & & & Fuel cost & $1.5 \mathrm{~L} \times 100$ & 150 & Fuel cost & & 150 \\
\hline Operation payment & - & - & - & - & - & 1500 & & & 3000 \\
\hline Total cost & & & 16800 & & & 2700 & & & 4200 \\
\hline Total cost saved & 14100 & & & & & & 1500 & & \\
\hline Total no. of labor & 42 & & & 2 & & & 2 & & \\
\hline Labor saved & 40 persons & & & & & & 0 & & \\
\hline
\end{tabular}

Source Authors' estimation based on field survey, 2017

Table 2 Cost-Benefit analysis of Rice Transplanter and Reaper Machine for 10 acres of land for 6 months period

\begin{tabular}{|c|c|c|}
\hline \multirow{2}{*}{ Items } & \multicolumn{2}{|l|}{ Cost (Tk.) } \\
\hline & For 1 acre & For 10 acres \\
\hline Initial investment $(390000+170000)$ & & 560000 \\
\hline Labor Cost saved & 14100 & 141000 \\
\hline Total Income & 14100 & 141000 \\
\hline \multicolumn{3}{|l|}{ Cost items } \\
\hline Labor cost & 900 & 9000 \\
\hline Fuel cost & 300 & 3000 \\
\hline Depreciation @5\% & 2800 & 28000 \\
\hline Repair \& Maintenance @5\% & 2800 & 28000 \\
\hline Project manager salary @Tk. 5000 per month & 600 & 30000 \\
\hline Shade Rent @Tk.1800 per month & 1080 & 10800 \\
\hline Repayment of Loan@ 9\% for 6 months & 1220.8 & 12208 \\
\hline Total cost & 9700.8 & 97008 \\
\hline Net income or profit & 4400 & 44000 \\
\hline Approximate salvage value at the ending of the project & \multicolumn{2}{|l|}{ Tk.48000 } \\
\hline Income from salvage value @ 6 months & \multicolumn{2}{|l|}{8000} \\
\hline Total net income & \multicolumn{2}{|c|}{$44000+8000=52000$} \\
\hline Annual total income & \multicolumn{2}{|l|}{104000} \\
\hline Expected project duration @ 5 years & \multicolumn{2}{|l|}{ Tk. 520000} \\
\hline
\end{tabular}

Source Authors' calculation based on field survey, 2017.

\section{Impact for the smallholders in Bangladesh}

1. Reduced the labor shortage crisis of the community farmers;

2. Minimized the cost of production; and

3. Community farmers' livelihood has been improved significantly.

\section{Acknowledgment}

This research is made possible by the support of the American People provided to the Feed the Future Innovation Lab for Sustainable Intensification through the United States Agency for International Development (USAID). Program activities are funded by USAID under Cooperative Agreement No. AID-OAA-L-14-00006.

\section{Conflicts of interest}

The contents are the sole responsibility of the authors and do not necessarily reflect the views of USAID or the United States Government

\section{References}

1. Gerland P, Raftery AE, Sevčíková , et al. World population stabilization unlikely this century. Science. 2014;346(6206):234-237.

2. Godfray HCJ, Garnett T. Food security and sustainable intensification. Philos Trans R Soc B Biol Sci. 2014;369(1639):1-10. 